\title{
Distribution, habitat characteristics, and diet of freshwater turtles in the surrounding area of the Seomjin River and Nam River in southern Korea
}

\author{
Heon-Joo Lee ${ }^{1}$ and Daesik Park ${ }^{2, *}$ \\ ${ }^{1}$ Department of Biology, Kangwon National University, Chuncheon 200-701, Korea \\ ${ }^{2}$ Division of Science Education, Kangwon National University, Chuncheon 200-701, Korea
}

In this study, we evaluated the distribution, habitat characteristics, and diet of two Korean freshwater turtle species (Chinemys reevesii, Pelodiscus sinensis) and an invasive turtle species (Trachemys scripta elegans) in the area surrounding the Seomjin River and the Nam River. We surveyed basking turtles in multiple locations along a 48-km stretch of the Seomjin River and in 99 reservoirs distributed along the Seomjin and Nam rivers from June to September, 2009. We observed 8 and 6 red-eared turtles in 3 reservoirs and at 3 sites in the Seomjin River, respectively, and 33 Reeve's turtles in 9 reservoirs. There were also 28 and 16 mud turtles detected at 15 sites along the Seomjin River and in 8 reservoirs, respectively. Among the 14 biotic and abiotic habitat characteristics that might influence the abundance of freshwater turtles in reservoirs, only the distance between a reservoir and the nearest residential areas was correlated negatively with abundance. With regard to the diet, all Reeve's and red-eared turtles investigated were determined to forage on water snails. Some turtles also foraged on vegetation and aquatic invertebrates. Additionally, we found fish in the stomach of one of the Reeve's turtles, and dragonflies in the stomachs of two red-eared turtles.

Key words: diet, distribution, mud turtle, red-eared turtle, Reeve's turtle

\section{INTRODUCTION}

There are approximately 290 different turtle species; among them, 24 species are listed as critically endangered species, 48 as endangered species, and 60 as vulnerable species by the International Union for the Conservation of Nature (IUCN) (Gibbons et al. 2000, Halliday and Adler 2006, IUCN 2010). In order to successfully conserve or restore a turtle species, understanding its habitat characteristics and life history may be a critically important step (Jones 2002). In developed countries, some studies have previously been conducted on the assemblage of turtle species in natural habitats (Vogt and Guzman 1988, Bodie et al. 2000, Segurado and Figueiredo 2007, Haramura et al. 2008), life historical components such as diet, basking site, and nesting site (Bury 1986, Perez-Santigosa et al. 2008, Platt et al. 2009), biotic and abiotic characteristics of natural habitats (Aresco 2009), and captive breeding and developing headstart programs (Grassman et al. 1984, Goode 1994). Based on the results of these studies, projects have been initiated for the conservation and restoration of endangered freshwater turtle species, including European pond turtles (Gariboldi and Zuffi 1994, Rivera and Fernandez 2004, Balázs and Györffy 2006, Schweitzer et al. 2008) and western pond turtles (Reese 1996, Hays et al. 1999). On the contrary, only a limited number of studies of freshwater turtles in South Korea have been conducted thus far. Studies have reported (c) This is an Open Access article distributed under the terms of the Creative Commons Attribution Non-Commercial License (http://creativecommons.org/licenses/by-nc/3.0/) which permits unrestricted non-commercial use, distribution, and reproduction in any medium, provided the original work is properly cited.
Received 31 March 2010, Accepted 29 April 2010

${ }^{*}$ Corresponding Author

E-mail: parkda@kangwon.ac.kr

Tel: +82-33-250-6739 
the rough distribution of freshwater turtles in South Korea (Song 2007), the distribution and management of the red-eared turtle in Jeju-do (Ministry of Environment of Korea 2003, Oh and Hong 2007), and the morphology and genetic diversity of the Reeve's turtle (Eo 2006).

There are three freshwater species in South Korea: two endemic species and one invasive species (Song 2007). Reeve's turtles (Chinemys reevesii) are detected in Korea, Japan, Taiwan, and China, and they are omnivorous freshwater turtles. They lay 4-6 eggs in sandbars at the edge of water bodies between June and August (Kang and Yoon 1975, Haramura et al. 2008). In South Korea, Reeve's turtles are designated both as an endangered category level II species by the Ministry of Environment of Korea (MEK) and as a natural monument by the Cultural Heritage Administration of Korea. Mud turtles (Pelodiscus sinensis) reside in Korea and Japan and prefer habitats with sand or pebbles at the bottoms of bodies of water. They are generally carnivorous and lay eggs between May and July (Kang and Yoon 1975). Red-eared turtles (Trachemys scripta elegans) have been designated by the IUCN as one of the 100 worst invasive species in the world, and they now live in many countries (Lowe et al. 2000). In South Korea, red-eared turtles were initially imported as pets in the 1970s. Between 1996 and 2000, approximately 6 million turtles were released into Korean freshwater bodies by people releasing their pets and/or releasing them as a component of Buddhist ceremonies (Bang et al. 2006). This species has been listed by the MEK as an ecosystem disturbance species since 2001.

In order to determine the distribution, habitat characteristics, and diet of freshwater turtles in the surrounding area of the Seomjin River and the Nam River in southern Korea, we conducted field surveys of basking freshwater turtles and analyzed food items in the stomach or feces of caught turtles.

\section{MATERIALS AND METHODS}

\section{Distribution and habitat characteristics of fresh- water turtles}

We surveyed basking freshwater turtles in multiple locations along the Seomjin River and in ponds and reservoirs distributed along the Seomjin River and Nam River in Jeollabuk-do and Gyeongsangnam-do province in 2009. First, we surveyed basking freshwater turtles in multiple locations along a 48-km stretch of the Seomjin River once between June 17 and June 26 in 2009. To sur- vey basking turtles, we slowly drove a car down the riverside road and stopped frequently in places where we could readily observe good basking sites, such as rocks. We used binoculars (UCF $\mathrm{X}_{\mathrm{II}}, 16 \times 25$; Pentax, Tokyo, Japan) to observe the turtles. Whenever one or more turtles were detected, the number observed and the locations on the map $(1: 5,000)$ were recorded. We did not evaluate the characteristics of riverine habitats in this study.

Additionally, we surveyed basking freshwater turtles in 11 agricultural ponds and 88 reservoirs distributed along the Seomjin River and Nam River, where each body of water was visited twice over four field trips between June 16-27, August 1-5, August 25-28, and September 2-10, 2009. Hereafter, we will consider each pond as a reservoir. To survey the turtles, we initially attempted to observe turtles at a distance using binoculars to minimize disturbances. Whenever necessary, however, we crawled cautiously to the boundary of a reservoir, and observed the turtles basking on logs and rocks, and/or on the water surface. After that, we walked slowly along the reservoir's boundaries while searching for additional turtles.

After surveying the turtles, we evaluated 14 different habitat characteristics (Table 1) in each reservoir. We ini-

Table 1. Abiotic and biotic habitat characteristics of the reservoirs where we observed and did not observe the freshwater turtles Chinemys reevesii, Trachemys scripta elegans, or Pelodiscus sinensis

\begin{tabular}{|c|c|c|}
\hline $\begin{array}{l}\text { Freshwater turtles } \\
\text { Characteristics }\end{array}$ & $\begin{array}{l}\text { Observed } \\
(N=15)\end{array}$ & $\begin{array}{l}\text { Not observed } \\
\quad(N=84)\end{array}$ \\
\hline Size of reservoir (ha) & $1.2 \pm 0.4$ & $1.1 \pm 0.2$ \\
\hline $\begin{array}{l}\text { Depth of reservoir } \\
(1,<5 \mathrm{~m} ; 2,6-10 \mathrm{~m} ; 3,>11 \mathrm{~m})\end{array}$ & $1.7 \pm 0.1$ & $1.5 \pm 0.1$ \\
\hline Altitude of reservoir (m) & $89.7 \pm 9.1$ & $122.9 \pm 11.0$ \\
\hline Plant cover index of reservoir (\%) & $16.3 \pm 6.2$ & $28.8 \pm 3.9$ \\
\hline Dissolved oxygen (DO) & $9.9 \pm 0.7$ & $8.9 \pm 0.3$ \\
\hline $\mathrm{pH}$ & $8.7 \pm 0.2$ & $8.6 \pm 0.1$ \\
\hline Turbidity & $4.4 \pm 1.6$ & $5.9 \pm 1.4$ \\
\hline Number of basking sites & $9.9 \pm 4.3$ & $6.1 \pm 1.4$ \\
\hline $\begin{array}{l}\text { Size of available sandbar* } \\
\left(1,0-5 \mathrm{~m}^{2} ; 2,6-25 \mathrm{~m}^{2} ; 3,>26 \mathrm{~m}^{2}\right)\end{array}$ & $1.5 \pm 0.2$ & $1.4 \pm 0.1$ \\
\hline $\begin{array}{l}\text { Size of available grassland* } \\
\left(1,0-5 \mathrm{~m}^{2} ; 2,6-25 \mathrm{~m}^{2} ; 3,>26 \mathrm{~m}^{2}\right)\end{array}$ & $2.3 \pm 0.2$ & $2.2 \pm 0.1$ \\
\hline Presence of bullfrog (\%) & $6(40)$ & $24(28.24)$ \\
\hline $\begin{array}{l}\text { Distance to the nearest } \\
\text { mountain }(\mathrm{m})\end{array}$ & $9.1 \pm 3.5$ & $10.4 \pm 2.4$ \\
\hline $\begin{array}{l}\text { Distance to the nearest } \\
\text { residential area }(\mathrm{m})^{\dagger}\end{array}$ & $134.8 \pm 73.3$ & $139.5 \pm 15.5$ \\
\hline Distance to the nearest river $(\mathrm{km})$ & $1.1 \pm 0.4$ & $1.3 \pm 0.1$ \\
\hline
\end{tabular}


tially measured the size, altitude, and depth of the reservoirs, the plant cover index of the water surface, the dissolved oxygen (DO) level, the $\mathrm{pH}$, and the water's turbidity. Additionally, we measured the shortest distance between a reservoir and the nearest mountain, residential area, and river or main tributary. The size of a reservoir, measured as the surface area, was estimated using satellite images (2009 smash map data) obtained from a website (http://local.daum.net/map/). The difference in area between field calculations and map estimates was $1.1 \pm 0.8$ ha $\mathrm{SD}(N=19)$. As the deviation was relatively small, other area and distance measurements used in this study were always estimated from the satellite image. The depths of the reservoirs were scored as 1,2 , or 3 for shallow $(<5 \mathrm{~m})$, medium $(6-10 \mathrm{~m})$, and deep ( $>11 \mathrm{~m})$ reservoirs, respectively. For nominal data regarding habitat characteristics, two people separately estimated values, after which these values were averaged. The altitude of a reservoir was measured using a GPS unit (Garmin, Taiwan) at the boundary of the reservoir. The plant cover index was estimated in $10 \%$ increments by two people, and then these estimates were averaged. DO levels were determined using a DO-5Z DO meter (Kasahara Chemical Instrument, Saitama, Japan), and $\mathrm{pH}$ was assessed using an Ecoscan pH 5/6 meter (Eutech Inc., Ayer Rajah Crescent, Singapore). We first collected approximately $200 \mathrm{~mL}$ of water at a depth of $30 \mathrm{~cm}$ and a distance of $1 \mathrm{~m}$ from the reservoir's boundary, and the values were measured to 0.1 units. To determine the turbidity, we transported the water into the laboratory and measured it with a digital turbidimeter (2100P; Hach, Loveland, CO, USA). The nearest mountain was the nearest mountain with an area in excess of 10 ha as measured on the satellite image map; the nearest residential area was the nearest town containing more than 5 houses; and the nearest river was the nearest main river, such as the Seomjin or Nam rivers, or the nearest main tributary, such as the Deokcheon and Yangcheon rivers. Additionally, we recorded the number of basking sites and the size of the sandbar and grassland directly adjoining a reservoir. We determined the existence of bullfrogs, which were considered potential predators. The number of basking sites was calculated as the sum of the numbers of rocks, logs $(>10 \mathrm{~cm}$ diameter), and artificial constructions that were exposed on the water surface, such as concrete blocks for irrigation. For the size of the sandbar and grassland, we scored 1,2 , or 3 points for small $\left(0-5 \mathrm{~m}^{2}\right)$, medium $\left(6-25 \mathrm{~m}^{2}\right)$, and large $\left(>26 \mathrm{~m}^{2}\right)$ sandbars and grasslands, respectively. For the existence of bullfrogs, we observed the adults directly and heard their calls while walking for 10 minutes along the boundary of a reservoir; we did not, however, check for the existence of tadpoles.

\section{Diet of freshwater turtles}

To evaluate the diets of freshwater turtles, we caught the turtles in 6 reservoirs between July 25 and November 5,2009 . We designed a new bait-based capturing trap, and it was successful (Fig. 1). We placed the traps in basking sites and checked the turtles 24 hours after placing the traps. We used pork as bait. When a turtle was captured, we applied a stomach flushing method (Legler 1977) in the field in order to collect food items. To ease the insertion of silicon tubes ( $4.5 \mathrm{~mm}$ outer diameter) into the stomach, we partially anesthetized the neck muscles of the turtles by injecting anesthesia $(30 \mathrm{mg} / \mathrm{kg}$ body weight Zoletil 50; Vivric, Seoul, Korea). In order to induce the regurgitation of food items, we delivered approximately 100-200 mL tap water into the stomach and individually maintained the regurgitated food items in $95 \% \mathrm{EtOH}$ until analysis. When the length of the ventral carapace of a turtle was shorter than $7.0 \mathrm{~cm}$, we brought the turtle into

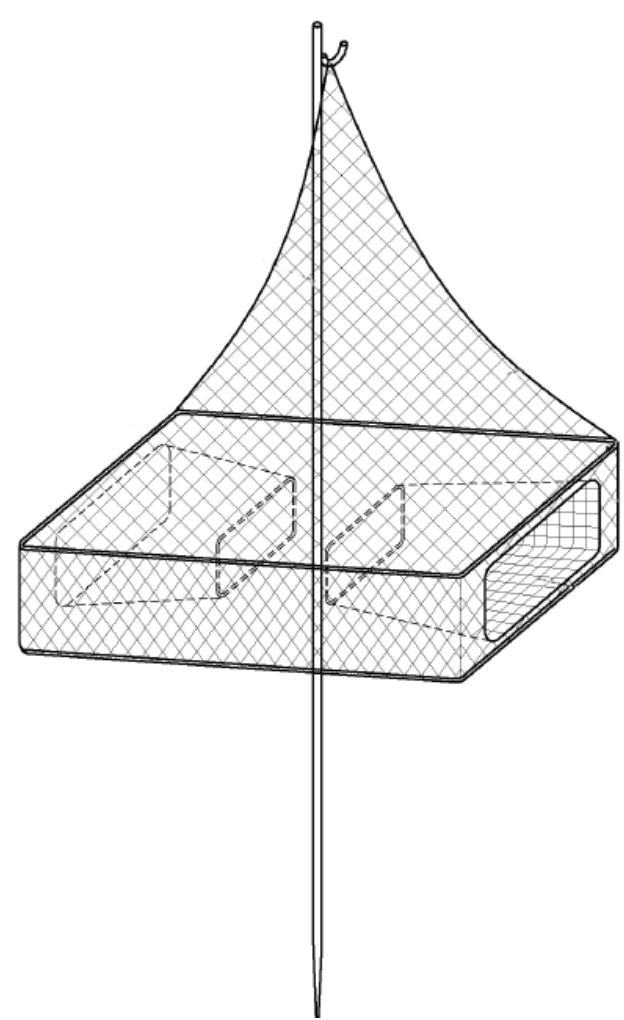

Fig. 1. Diagram of the bait trap for catching freshwater turtles invented and used in this study. The trap has two entrances and a space for breathing for the caught turtles. Also, the height of the trap is adjustable so that it can be placed at various depths. We hung pork as bait in the center of the trap. 
a field house and maintained it individually in a plastic box with water at a depth of $5 \mathrm{~cm}$ for 12-15 hours in order to collect fecal samples.

Food items in the stomach and feces were investigated under a dissecting microscope (Zeus, China) or microscope (Eclipse 50i; Nikon, Seoul, Korea) in the laboratory. We identified food items in terms of class or order (Table 2 ), and then classified them further into genera or species. When possible, we counted the number of items. The criteria for an individual in each classification category were as follows: whole body or complete head bone of a fish, main body or gill cover of a water snail, complete head parts of a larval caddisfly or adult dragonfly or any appendages of insects without any whole bodies or heads, a flower possessing a complete calyx and petal, and plant seeds from sedges. In this study, we did not detect the main body and gill cover of water snails together in any turtles. For other food items, we described only the existence or absence of the items in the stomach or feces.

\section{Statistical analysis}

To compare the various habitat characteristics between the sites where we observed and did not observe freshwater turtles, we applied Mann-Whitney's U test because the data did not fulfill the normal distribution as- sumption (Kolmogorov-Smirnov, $P<0.05$ ). All data were analyzed via SPSS (SPSS Inc., Chicago, IL, USA) and expressed as the means \pm SE.

\section{RESULTS}

\section{Distribution and habitat characteristics of fresh- water turtles}

From the survey of multiple locations along a 48-km stretch of the Seomjin River, we observed 6 red-eared turtles (2.0 $\pm 1.0, N=3$; range, 1 to 3 ) at 3 sites and 28 mud turtles ( $1.9 \pm 1.3, N=15$; range, 1 to 5$)$ at 15 sites (Fig. $2 a$ ). The two species were detected together at only 1 site, and we observed no Reeve's turtles.

We surveyed 34 reservoirs along the Seomjin River (Fig. 2a) and 65 reservoirs along the Nam River (Fig. 2b), and observed a total of 54 turtles in 15 reservoirs. Thirtythree Reeve's turtles ( $3.7 \pm 2.1, N=9$; range, 1 to 7 ) were detected at 9 reservoirs, 8 red-eared turtles $(2.7 \pm 2.1, N=$ 3 ; range, 1 to 5 ) at 3 reservoirs, and 13 mud turtles (1.9 \pm $1.5, N=7$; range, 1 to 5 ) at 7 reservoirs. Reeve's turtles and red-eared turtles were detected together at 1 reservoir, and all three species were found together in 2 reservoirs.

The habitat characteristics between the reservoirs in

Table 2. Food items found in the feces (M2, M3 individuals only) or stomachs (other individuals) of eight specimens of Chinemys reevesii and five Trachemys scripta elegans

\begin{tabular}{|c|c|c|c|c|c|c|c|c|c|c|c|c|c|c|c|}
\hline \multirow{2}{*}{ Species } & \multirow{2}{*}{ Sex } & \multirow{2}{*}{$\begin{array}{c}\text { Cara- } \\
\text { pace } \\
\text { length } \\
(\mathrm{mm})\end{array}$} & \multirow{2}{*}{$\begin{array}{l}\text { Cyprinidae } \\
\text { (fish) }\end{array}$} & \multicolumn{3}{|c|}{$\begin{array}{l}\text { Mesogastropoda } \\
\text { (water snail) }\end{array}$} & \multirow{2}{*}{$\begin{array}{c}\text { Bradybae- } \\
\text { nidae } \\
\text { (snail) }\end{array}$} & \multirow{2}{*}{$\begin{array}{l}\text { Basomma- } \\
\text { tophora } \\
\text { (vivalvia) }\end{array}$} & \multirow{2}{*}{$\begin{array}{l}\text { Trichoptera } \\
\text { nymph } \\
\text { (caddisfly) }\end{array}$} & \multicolumn{2}{|l|}{ Insects } & \multicolumn{3}{|c|}{ Plants } & \multirow{2}{*}{$\begin{array}{l}\text { Zygnemataceae } \\
\text { (Spirogyra) }\end{array}$} \\
\hline & & & & $\begin{array}{l}\text { Main } \\
\text { body }\end{array}$ & $\begin{array}{l}\text { Gill } \\
\text { cover }\end{array}$ & $\begin{array}{c}\text { Parts of } \\
\text { body/Shell }\end{array}$ & & & & $\begin{array}{c}\text { Odonata } \\
\text { adult } \\
\text { (dragonfly) }\end{array}$ & $\begin{array}{c}\text { Un- } \\
\text { known }\end{array}$ & $\begin{array}{l}\text { Nymphaeaceae } \\
\text { flower }\end{array}$ & $\begin{array}{l}\text { Cypera- } \\
\text { ceae seed }\end{array}$ & $\begin{array}{c}\text { Un- } \\
\text { known }\end{array}$ & \\
\hline \multirow{7}{*}{$\begin{array}{l}\text { C. } \\
\text { reevesii }\end{array}$} & M1 & 80 & $+(2)$ & $+(21)$ & & & & & & & & $+(1)$ & & + & \\
\hline & M2 & 164 & & & & + & & + & $+(1)$ & & $+(1)$ & & $+(12)$ & + & + \\
\hline & M3 & 111 & & & $+(3)$ & + & & & & & $+(1)$ & & & + & \\
\hline & M4 & 84 & & & & + & & & & & & & & & \\
\hline & M5 & 83 & & & $+(1)$ & & & & & & & & & & \\
\hline & $\mathrm{F} 1$ & 112 & & & $+(20)$ & + & & & & & $+(1)$ & & & + & \\
\hline & F2 & 144 & & & & + & & & & & & & & & \\
\hline \multirow{5}{*}{$\begin{array}{l}\text { T. } \\
\text { scripta } \\
\text { elegans }\end{array}$} & M6 & 194 & & & $+(2)$ & & & & & $+(1)$ & & & & + & \\
\hline & M7 & 125 & & $+(10)$ & & + & $+(1)$ & & $+(3)$ & $+(1)$ & & $+(9)$ & & + & \\
\hline & M8 & 100 & & & & + & & & & & + & & & + & \\
\hline & $\mathrm{F} 4$ & 169 & & & & + & & & & & & & & & \\
\hline & F5 & 181 & & & & + & & & & & & & & & \\
\hline
\end{tabular}

Plus signs indicate the presence of a food item, and the numbers in brackets indicate the numbers of items counted. 


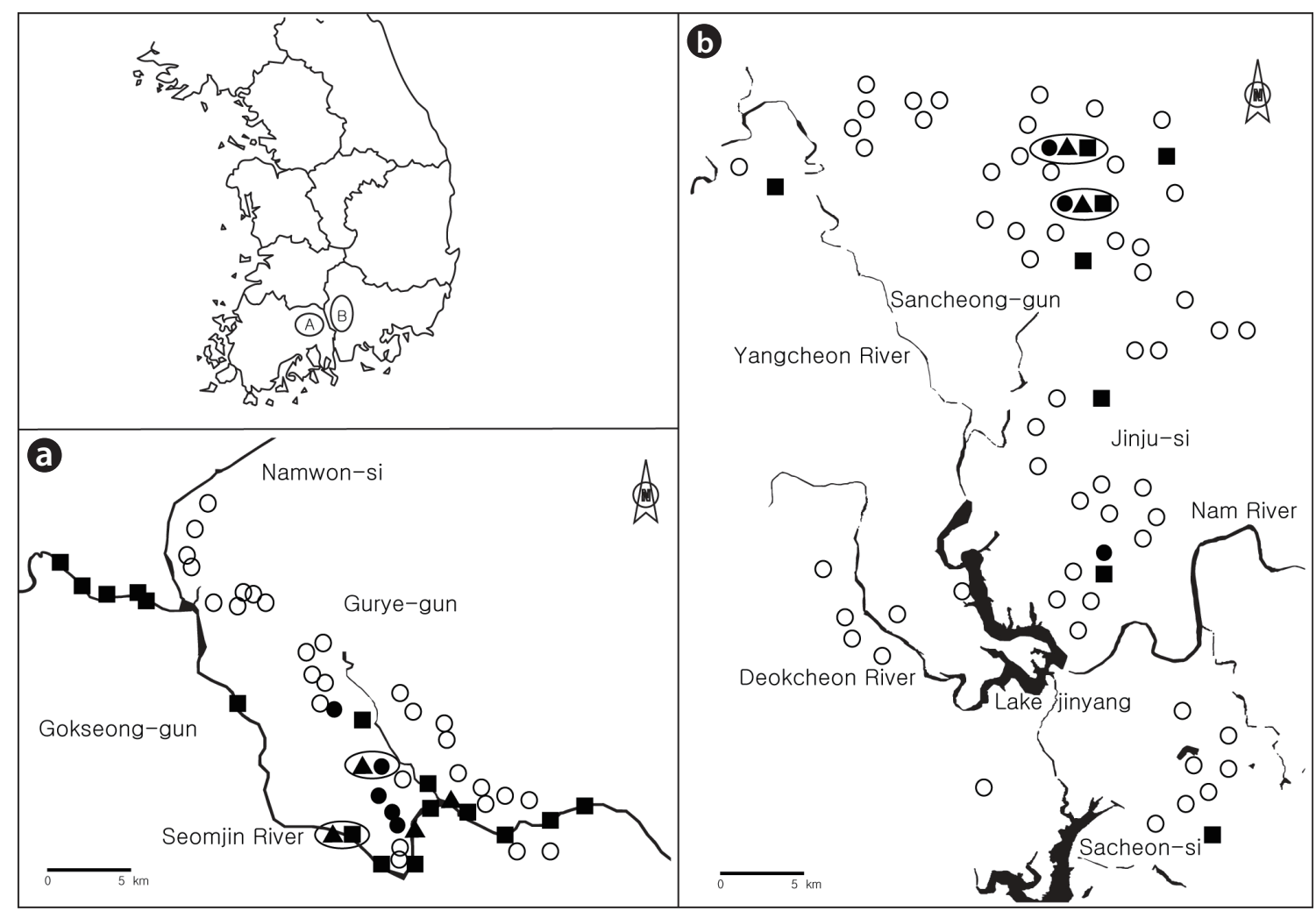

Fig. 2. Survey sites where the freshwater turtles Chinemys reevesii $(\bullet)$, Trachemys scripta elegans $(\boldsymbol{\Delta})$, and Pelodiscus sinensis $(\boldsymbol{\bullet})$ were observed (closed diagrams) and not observed (open circles) in 17 locations along a 48-km stretch of the Seomjin River and in 99 reservoirs distributed along the Seomjin and Nam rivers in Jeollabuk-do (a) and Gyeongsangnam-do (b) province, South Korea. When more than one species was observed at a site, we enclosed diagrams with a circle.

which we observed and did not observe turtles did not differ for any single turtle species (Mann-Whitney U test, $P>0.05$ for all cases). When we combined the turtles of the three species, the distance between a reservoir and the nearest residential area was found to be negatively correlated with the abundance of freshwater turtles $\left(\mathrm{U}_{15}\right.$, ${ }_{84}=422.50, P=0.043$ ) (Table 1 ).

\section{Diet of freshwater turtles}

We caught a total of 11 Reeve's turtles, 10 red-eared turtles, and 2 mud turtles, and successfully analyzed the dietary materials in the stomachs of 6 Reeve's turtles ( 3 males and 3 females) and 5 red-eared turtles ( 2 females and 3 males). We detected no food items in the stomach of mud turtles. We also analyzed the feces of two Reeve's turtles.

We detected water snails in the stomachs or feces of all of the Reeve's turtles and red-eared turtles examined herein (Table 2). Three Reeve's and three red-eared turtles were observed to forage on insects. One Reeve's turtle foraged on fish and one on spirogyra, and two red-eared turtles foraged on adult dragonflies. Five Reeve's turtles and three red-eared turtles foraged on plant materials, including the flowers, seeds, and other parts of plants.

\section{DISCUSSION}

The results of our survey of basking freshwater turtles revealed two important points. First, Reeve's turtles were found inhabiting lentic water bodies, whereas red-eared turtles and mud turtles were detected in both lentic and lotic water bodies. Second, very few Reeve's turtles and red-eared turtles were detected in the reservoirs.

Our results on the distribution of freshwater turtles are largely consistent with previous reports (Kang and Yoon 1975). Reeve's turtles are known to prefer to inhabit lentic waters, such as ponds and reservoirs, although they are also found in the lentic parts of a river (Kang and Yoon 1975, Haramura et al. 2008). By way of contrast, mud turtles tend to prefer water bodies with sand and pebbles at the bottom (Kang and Yoon 1975). During our surveys of the Seomjin River, we observed many adult and juvenile mud turtles and also juvenile red-eared turtles (personal observation), thereby suggesting that they prefer to 
inhabit lotic water bodies and might be breeding in the river.

In the reservoirs, we observed a very small number of freshwater turtles. In particular, we only observed juvenile Reeve's turtles in one reservoir, and observed no juvenile red-eared or mud turtles in the reservoirs surveyed. It has been estimated that a turtle population requires 50-70 individuals to persist over a long period of time (Reese 1996). Thus, most populations in the reservoirs investigated in this study may be facing extinction (Primack 1993). In particular, Reeve's turtles may be facing extinction in the studied areas, because we observed only juveniles in one reservoir, and their distribution was limited in lentic water bodies. Owing to their long longevity, turtles can be observed for 10-20 years after breeding ceases in a population (Gerlach 2008). When individuals are not continuously recruited into the population, the population will ultimately become extinct. Thus, there is an urgent need to further evaluate the current status of Korean endemic freshwater turtles, and particularly Reeve's turtles.

Among the 14 habitat characteristics, only the distance between a reservoir and the nearest residential areas was significantly negatively correlated with the abundance of freshwater turtles. That is, reservoirs that were located closer to residential areas tended to contain more freshwater turtles. This result indicates that the freshwater turtles observed in this study might be predominantly those that were transported or released by human beings. Generally speaking, the abundance of freshwater turtles at a given site depends on the number of available basking and nesting sites, food availability (Bodie et al. 2000, Segurado and Figueiredo 2007), the primary productivity of habitats, the abundance of predators (Aresco 2009), and the dispersal ability of juvenile and adult turtles (Roe et al. 2009). Even though many of these factors were included in this study, they were not found to be related to the abundance of freshwater turtles. These results may be attributable to our small samples and/or survey methods. We surveyed populations during only a single year, and did not conduct any underwater studies, such as analyses of substrate characteristics and counting turtles in hiding places or foraging underwater. The incomplete nature of our survey methods may be responsible for our small samples: 54 turtles in 15 reservoirs out of 99 reservoirs, which probably resulted in the low statistical power.

Our results demonstrated that the Reeve's turtle and red-eared turtle were omnivorous, and their diets largely overlapped. In particular, all turtles investigated in this study foraged on water snails. Reeve's turtles have been demonstrated to forage preferentially on water snails. In an experimental study, one Reeve's turtle consumed 2,000 water snails within a period of 8 weeks (Yoshie and Yusa 2008). In this study, the turtles also foraged on plants and seeds, larval caddisflies, and fish, thereby suggesting that their primary mode of foraging is underwater. It has been reported in previous studies that the red-eared turtle is omnivorous (Parmenter and Avery 1990, Chen and Lue 1998, Prévot-Julliard et al. 2007). In this study, the turtles were shown to forage on water snails, larval caddisflies, and some plants. We found adult dragonflies in the stomachs of two red-eared turtles, which suggested that they might forage on the water surface like the western pond turtle (Bury 1986). When several turtle species co-inhabit, their window of food items may overlap (Vogt 1981, Vogt and Guzman 1988). Thus, considering that the diets of Reeve's turtles and red-eared turtles overlapped, it might also be surmised that they compete for food.

Red-eared turtles, an invasive species, might negatively affect populations of Reeve's turtles, an endangered species, as well as populations of mud turtles in the field. Red-eared turtles are one of the worst invasive species in the world: they evidence profound reproductive ability in the field (Perez-Santigosa et al. 2008); they compete for basking sites with the endangered European pond turtle (Emys orbicularis) (Cadi and Joly 2003); and their activities may negatively affect the body weights and mortality of European pond turtles (Cadi and Joly 2004). In this study, red-eared turtles co-inhabited and shared food items with Reeve's turtles and mud turtles, thus indicating that they might compete for resources with endemic freshwater turtles. However, it is difficult to directly determine the negative effects of red-eared turtles on endemic freshwater turtles in our study, owing to the small number of samples. In order to conserve or restore the populations of Korean freshwater turtles, the effects of red-eared turtles on endemic turtles should be evaluated in the near future, and their populations should be controlled actively if necessary.

\section{ACKNOWLEDGMENTS}

We thank Hwan-Jin Hwang and Jae-Hyun Lee for their assistance in the field and Bit-Na Kim for preparing one of the figures. We thank Mr. Dong-Gi Choi for introducing the survey sites and providing field accommodations, Dr. Woo-Myeong Heo of Kangwon National University for lending us his turbidimeter, and Hwan-Yool Yong, Jong- 
Tae Yoo, Bo-Sook Kim, Kyeong-Hyun Eo, Mi-Hyun Yoo, Bok-Soo Bae, and Yoo-Cheong Jung of the Seoul Zoo for participating in the Chinemys reevesii Research Project. This study was permitted by the Cultural Heritage Administration of Korea and supported by the National Institute of Biological Resources in Korea.

\section{LITERATURE CITED}

Aresco MJ. 2009. Environmental correlates of the abundances of three species of freshwater turtles in lakes of northern Florida. Copeia 2009: 545-555.

Balázs E, Györffy G. 2006. Investigation of the European pond turtle (Emys orbicularis Linnaeus, 1758) population living in a backwater near the river Tisza, Southern Hungary. TISCIA 35: 55-64.

Bang SW, Byeon HG, Shim JH, Choi BJ, Lee SB, Moon YL, No BH, Sin GE, Park JH, Cheong JH. 2006. A Study for the Clarification of the Current Status of Introduced Organisms and for the Classification of Dangerous Classes to Korean Endemic Ecosystems. Ministry of Environment of Korea, Seoul. (in Korean)

Bodie JR, Semlitsch RD, Renken RB. 2000. Diversity and structure of turtle assemblages: associations with wetland characters across a floodplain landscape. Ecography 23: 444-456.

Bury RB. 1986. Feeding ecology of the turtle, Clemmys marmorata. J Herpetol 20: 515-521.

Cadi A, Joly P. 2003. Competition for basking places between the endangered European pond turtle (Emys orbicularis galloitalica) and the introduced Red-eared slider (Trachemys scripta elegans). Can J Zool 81: 1392-1398.

Cadi A, Joly P. 2004. Impact of the introduction of the redeared slider (Trachemys scripta elegans) on survival rates of the European pond turtle (Emys orbicularis). Biodivers Conserv 13: 2511-2518.

Chen TH, Lue KY. 1998. Ecological notes on feral populations of Trachemys scripta elegans in Northern Taiwan. Chelonian Conserv Biol 3: 87-90.

Eo KY. 2006. Studies on morphology, hematology, and genetic diversity of Korean Reeve's turtle (Chinemys reevesii). MS Thesis. Konkuk University, Seoul, Korea.

Gariboldi A, Zuffi MAL. 1994. Notes on the population reinforcement project for Emys orbicularis (Linnaeus, 1758) in a natural park of northwestern Italy. Herpetozoa 7: 83-89.

Gerlach J. 2008. Fragmentation and demography as causes of population decline in Seychelles freshwater turtles (Genus Pelusios). Chelonian Conserv Biol 7: 78-87.
Gibbons JW, Scott DE, Ryan TJ, Buhlmann KA, Tuberville TD, Metts BS, Greene JL, Mills T, Leiden Y, Poppy S, Winne CT. 2000. The global decline of reptiles, deja vu amphibians. BioScience 50: 653-666.

Goode JM. 1994. Reproduction in captive neotropical musk and mud turtles (Staurotypus triporcatus, S. salvinii, and Kinosternon scorpioides). In: Captive Management and Conservation of Amphibians and Reptiles (Murphy JB, Adler K, Collins JT, eds). Society for the Study of Amphibians and Reptiles, Ithaca, NY, pp 275-295.

Grassman MA, Owens DW, McVey JP, Marquez MR. 1984. Olfactory based orientation in artificially imprinted sea turtles. Science 224: 83-84.

Halliday T, Adler K. 2006. The New Encyclopedia of Reptiles and Amphibians. Oxford University Press, Oxford.

Haramura T, Yamane M, Mori A. 2008. Preliminary survey on the turtle community in a lotic environment of the Kizu river. Curr Herpetol 27: 101-108.

Hays DW, McAllister KR, Richardson SA, Stinson DW. 1999. Washington State Recovery Plan for the Western Pond Turtle. Washington Department of Fish and Wildlife, Olympia, WA.

IUCN. 2010. IUCN red list of threatened species. Ver. 2010.1. http://www.iucnredlist.org/. Accessed 21 March 2010.

Jones CG. 2002. Reptiles and amphibians. In: Handbook of Ecological Restoration, Vol 1: Principles of Restoration (Perrow MR, Davy AJ, eds). Cambridge University Press, Cambridge, pp 355-375.

Kang YS, Yoon IB. 1975. Illustrated Encyclopedia of Fauna and Flora of Korea, Vol. 17. Amphibia and Reptilia. SamHwa Press, Seoul.

Legler JM. 1977. Stomach flushing: a technique for Chelonian dietary studies. Herpetologica 33: 281-284.

Lowe S, Browne M, Boudjelas S, De Poorter M. 2000. 100 of the World's Worst Invasive Alien Species: A Selection from the Global Invasive Species Database. The Invasive Species Specialist Group (ISSG)/A specialist group of the Species Survival Commission (SSC) of the World Conservation Union (IUCN), Auckland.

Ministry of Environment of Korea. 2003. Results of national surveys on the distribution of the Red-eared turtle (Trachemys scripta elegans) in South Korea. http://epic. kdi.re.kr/epic/epic_view.jsp?num=65793\&menu=1. Accessed 21 March 2010.

Oh HS, Hong CE. 2007. Current conditions of habitat for Rana catesbeiana and Trachemys scripta elegans imported to Jeju-do, including proposed management plans. Korean J Environ Ecol 21: 311-317.

Parmenter RR, Avery HW. 1990. The feeding ecology of the slider turtle. In: Life History and Ecology of the Slider 
Turtle (Gibbons JW, ed). Smithsonian Institute Press, Washington, DC, pp 257-266.

Perez-Santigosa N, Diaz-Paniagua C, Hidalgo-Vila J. 2008. The reproductive ecology of exotic Trachemys scripta elegans in an invaded area of southern Europe. Aquat Conserv Mar Freshwater Ecosyst 18: 1302-1310.

Platt SG, Hall C, Liu H, Borg CK. 2009. Wet-season food habits and intersexual dietary overlap of Florida box turtles (Terrapene carolina bauri) on National key deer wildlife refuge, Florida. Southeast Nat 8: 335-346.

Prévot-Julliard AC, Gousset E, Archinard C, Cadi A, Girondot M. 2007. Pets and invasion risks: is the slider turtle strictly carnivorous? Amphibia-Reptilia 28: 139-143.

Primack RB. 1993. Essentials of Conservation Biology. Sinauer Associates, Sunderland, MA.

Reese DA. 1996. Comparative demography and habitat use of Western pond turtles in Northern California: the effects of damming and related alterations. PhD Dissertation. University of California, Berkeley, CA, USA.

Rivera AC, Fernandez CA. 2004. A management plan for the European pond turtle (Emys orbicularis) populations of the Louro river basin (Northwest Spain). Biologia 59(Suppl 14): 161-171.

Roe JH, Brinton AC, Georges A. 2009. Temporal and spatial variation in landscape connectivity for a freshwater turtle in a temporally dynamic wetland system. Ecol Appl 19: 1288-1299.

Schweitzer S, Prinzinger R, Wicker R. 2008. Reintroduction project of the turtle Emys orbicularis in Hesse (Germany): basic steps and first results. Revista Espanola de Herpetologia 22: 121-130.

Segurado P, Figueiredo D. 2007. Coexistence of two freshwater turtle species along a Mediterranean stream: the role of spatial and temporal heterogeneity. Acta Oecol 32: 134-144.

Song JY. 2007. Current status and distribution of reptiles in the Republic of Korea. Korean J Environ Biol 25: 124-138.

Vogt RC. 1981. Food partitioning in three sympatric species of Map turtle, Genus Graptemys (Testudinata, Emydidae). Am Midl Nat 105: 102-111.

Vogt RC, Guzman SG. 1988. Food partitioning in a neotropical freshwater turtle community. Copeia 1988: 37-47.

Yoshie H, Yusa Y. 2008. Effects of predation on the exotic freshwater snail Pomacea canaliculata (Caenogastropoda: Ampullariidae) by the indigenous turtle Chinemys reevesii (Testudines: Geoemydidae). Appl Entomol Zool 43: 475-482. 